\title{
De Notabelen van het Eerste Keizerrijk (1804-1814). Het Scheldedepartement.
}

\author{
Conny DEVOLDER ${ }^{1}$
}

\begin{abstract}
Begrenzing en samenstelling van de onderzochte groep. Methodologie en bronnen.
\end{abstract}

Zoals de titel laat vermoeden, kadert deze studie in een breder, internationaal gericht opzet. L. Bergeron (directeur van de Ecole Pratique des Hautes Etudes, VIe section) en G. Chaussinand-Nogaret lagen aan de basis van dit project. Anno 1973 nam het Centre National de la Recherche Scientifique het onderzoek op zich ${ }^{2}$. Studie-object vormen 'de notabelen', een vage, veelduidige, maar operationele notie. Waarom behoort men tot de notabiliteit ? Het antwoord ligt vervat in de lijsten van de arrondissementele en departementale kiescolleges, van de 600 meest belasten per departement. Deze bronnen werden aan een kwantitatief onderzoek onderworpen. Naarmate de studie vorderde, tekenden zich de krijtlijnen af van een welbepaalde economisch-fiscale categorie.

Na het waarom, het hoe. Hoe wordt men notabele ? Langs welke wegen, volgens welke strategieën. Bij dergelijke, geïndividualiseerde aanpak, dringt zich een verdere begrenzing van het onderzoeksobject op. Onze collectieve biografie, een typologie van de notabelen, kadert in deze onderzoeksfase. $\mathrm{Ze}$ wil een antwoord zijn op laatstgenoemde vraagstelling. We zullen onze aandacht toespitsen op de 'grote notabelen', de meest notoire, de sociaalpolitiek invloedrijkste notabelen. Hun namen halen we uit vier zogenaamde

1 Dit artikel is een bewerking van mijn licentiaatsverhandeling $\mathbf{C}$. DEVOLDER, De notabelen van het Eerste Keizerrijk (1804-1814). Het Scheldedepartement, Gent, R.U.G., 1990, 3 delen, XXIV + 773 p. Voor een uitgebreid voetnotenapparaat verwijzen we naar de corresponderende biografieën (delen I en II), evenals naar de prosopografische analyse van de notabelen (deel III).

2 De onderzoeksresultaten worden gepubliceerd naarmate het onderzoek vordert. Daarenboven opteert het C.N.R.S. voor een regionale groepering van de studies. Concreet betekent dit dat het Scheldedepartement zal gebundeld worden met 2 Waalse departementen. De publicatie wordt in de loop van 1992 verwacht. 


\section{CONNY DEVOLDER}

basislijsten : $1^{\circ}$. Lijst van de 30 meest belasten van het Scheldedepartement, 18 vendémiaire - 20 brumaire XII [11-10-1803 - 12-11-1803], $2^{\circ}$. Lijst van diegenen die zich onderscheiden door hun talenten of bewezen diensten, doch niet opgenomen zijn in de lijst van de meest belasiten van het Scheldedepartement, 5 Brumaire an XII [28-10-1803] [5 personen], $3^{\circ}$. Lijst van de 60 meest vooraanstaande (qua fortuin, publieke en private deugden) eigenaars van het Scheldedepartement, 27 prairial an 13 [16-6-1805], $4^{\circ}$. Lijst van de meest markante personen van het Scheldedepartement, 19-7-1812 [62 personen] ${ }^{3}$. De aldus bekomen groep omvat 105 notabelen ${ }^{4}$.

De 'Lijst van de 60' moest tenminste 20 personen bevatten die een groot deel van hun fortuin in nationale goederen hadden ${ }^{5}$. Bij het opstellen van de lijst, kwalificeert de prefect van het bestudeerde departement 22 notabelen als voornaam bezitter van nationale goederen. Uit het onderzoek blijkt dat 29 verwervers van in het Scheldedepartement gesitueerde nationale goederen ingeschreven staan op de 'Lijst van de 60'. Drie onder hen kopen echter pas na de redactie van voornoemde lijst. De resterende 26 vertegenwoordigen $43 \%$ van de lijst. We noteren eveneens dat 28 verwervers van zwarte goederen ingeschreven staan op de 'Lijst van de markante personen'. Ze vertegenwoordigen $45 \%$ van laatstgenoemde lijst.

Uit de 'Lijst van de meest markante personen' worden de voorzitters van de kantonnale vergaderingen, evenals de leden van de kiescolleges, gerecruteerd ${ }^{6}$. De minister van binnenlandse zaken gaf volgende instructies: "La deuxieme liste désignera les personnes les plus marquantes de votre département; de ce nombre sont : $1^{\circ}$. Les membres des premiers corps de l'etat originaires $d u$ département ou qui y ont fixé leur domicile politique : il faut en excepter les membres du Corps législatif, lesquels, d'apres les dispositions de l'article 34 de l'acte des constitutions de l'Empire, en date du 16 thermidor an 10, ne peuvent, pendant la durée de leurs fonctions législatives, voter dans leurs collèges électoraux, ni à plus forte raison les presider; $2^{\circ}$. Les fonctionnaires

3 RAG, Fonds Scheldedepartement, 2219/1, 3175/3. AN, F 1cIII Escaut 3.

4 Twee notabelen, vermeld op eerstgenoemde lijst, konden we niet identificeren, nl. Dhaene, door de prefect gekwalificeerd als "Homme d'esprit. Vit for Retiré" en Du Vasier, "Vieillard inferme". De 'Lijst van de 60' maakt gewag van een zekere Schamp-Vaernewyck Jean. De verstrekte identificatiegegevens laten niet toe uit te maken of het hier Jean-Baptiste dan wel Jean-Gilles Schamp, twee broers, getrouwd met twee zusters, betreft. Beiden werden weerhouden. Voor een naamlijst van de notabelen, zie bijlage.

5 A. MAUREAU, G. PEYRON-MONTAGNON, Grands notables du Premier Empire. 1. Vaucluse, Ardèche, Paris, C.N.R.S., 1978, p. IX.

6 A. MAUREAU, G. PEYRON-MONTAGNON, Grands notables..., p. IX. 


\section{DE NOTABELEN VAN HET SCHELDEDEPARTEMENT}

militaires ou civils les plus distingués, les propriétaires les plus considérables, les hommes issus des familles les plus illustres, les uns et les autres, soit qu'ils soient originaires du département, soit qu'ils y avaient fixé leur domicile politique. Cette liste devra contenir 60 personnes au moins (...) $)^{\prime \prime}$.

Zoals gezegd bestaat de gevolgde methode in het opmaken van biografieèn van voornoemde personen. Deze werkwijze maakt het mogelijk zowel de gemeenschappelijke kenmerken van de groep als de unieke factoren van elk individu te onderscheiden. De identificatie van een notabele en de reconstructie van zijn levensloop kwam langzaam tot stand door het steeds weer raadplegen en vergelijken van primaire en secundaire bronnen, evenals accidentele vondsten. Tot eerstgenoemden rekenen we het Fonds Scheldedepartement van het Rijksarchief van Gent (RAG, F Sd) en de reeksen F 1 bII en F 1cIII van de Archives Nationales de Paris (AN). Bij het depouilleren van deze overheidsarchieven ging onze aandacht in de eerste plaats uit naar benoemingsbesluiten en lijsten van verkozenen, aangestelden of kandidaten voor één of andere politieke of juridische functie.

De geciteerde basislijsten gaven ons reeds een idee van wat dergelijke lijsten zoal aan inlichtingen kunnen verstrekken : (al dan niet juiste) familieen voornamen, domicilie, geboorteplaats en -datum, burgelijke staat (met inbegrip van het aantal kinderen), huidige functie, functies vo6r en na 1789 , informatie inzake inkomen of belastingsbedrag, toegewijdheid en genoten achting. Welke ook de onvolkomenheden van de bronnen zijn, toch vormen ze een goede sleutel tot een beter inzicht in de sociaal-politieke geschiedenis. Wanneer men de gegevens in een bredere context plaatst, kan een grote mate van correctheid bereikt worden. We wijzen er nog eens op dat de lijsten dateren uit de beginperiode van de administratieve statistiek, en daarmee is veel gezegd. Onmisbare gidsen waren eveneens de doctoraatsverhandeling van Prof. dr. H. Balthazar, de werken van P. Van Hille en J. Neve, de Gentse Wegwijzer, de ruim voorhanden zijnde genealogische staten... om er maar enkele te noemen ${ }^{8}$.

7 RAG, $F$ Sd, 4537/24, De minister van binnenlandse zaken aan de perfect van het Scheldedepartement, Parijs, 9-7-1812.

8 H. BALTHAZAR, Structuren en mutaties bij het politiek personeel. Een studie over het sociaal wisselingsproces te Gent in de vormingsjaren van de Hedendaagse Tijd (1780-1850), Gent, R.U.G. (onuitgegeven doctoraatsverhandeling), 1970, I + II, LX + 538 p. + III, 471 p. P. VAN HILLE, Het Hof van Beroep van Brussel en de rechtbanken van Oost- en WestVlaanderen onder het Franse Bewind - 1800-1814, Handzame, Familia et Patria, 1970 , VII + 212 p. J. NEVE, Gand sous la domination française (1792-1814), Gand, A. Buyens, 1927, 401 p. Nieuwen Almanach, curieus en util voor het 


\section{CONNY DEVOLDER}

\section{Het geografisch kader : het Scheldedepartement.}

Het bestudeerde departement is een microcosmos in het immense franse keizerrijk, maar voorwaar niet de eerste de beste ! Volgens het besluit van 9 floréal IV (9-5-1800) betreffende de verdeling van de persoonlijke, mobiliaire en weeldebelasting over de 98 Franse departementen, komt het Scheldedepartement met $868.000 \mathrm{fr}$. op de vierde plaats, na de departementen van Seine (5.043.000 fr.), Seine Inférieure (1.340.000 fr.) en Nord (908.000 fr.) ${ }^{9}$. In hiernavolgende uiteenzetting schetsen we het ruimtelijk kader van onze studie : het bij decreet van de Nationale Conventie de dato 9 vendémiaire IV (1-10-1795) gecreëende Scheldedepartement ${ }^{10}$.

Tijdens de tweede Franse periode wordt het oude graafschap Vlaanderen of tenminste het gebied dat de Habsburgers tevoren er nog van in handen hadden, opgedeeld in twee arrondissementen : Oost- en West-Vlaanderen, met ais respectievelijke hoofdplaatsen Gent en Ieper (15-10-1794). Een goede maand later wordt ZeeuwsVlaanderen voorlopig aan eerstgenoemd arrondissement toegevoegd (21-11-1794). Op 31 augustus 1795 wordt de administratie opnieuw gewijzigd en is er voor het eerst sprake van het 'arrondissement ou département de l'Escaut'. Deze benaming zal bewaard blijven tot het einde van het Franse bewind. Daarna spreekt men over de provincie Oost-Vlaanderen. Inmiddels is Zeeuws-Vlaanderen er wel van afgescheiden (1807).

Zeeuws-Vlaanderen krijgt zijn definitieve regionale indeling in februari 1796. Het gebied vormt, aangevuld met Kaprijke en Assenede het vierde arrondissement binnen het Scheldedepartement. De zetel van de onderprefectuur verhuist van Sas-van-Gent, een geïsoleerd stadje, naar het belangrijkere Eeklo. De inlijving van Zeeuws-Vlaanderen in het departement is de integratie van twee gebieden die door geen natuurlijke grenzen gescheiden zijn en elkaar economisch completeren : het geïndustrialiseerde dichtbevolkte Vlaanderen en de vruchtbare Zeeuws-Vlaamse poldergronden.

\footnotetext{
Jaer ...ofte den getrouwen Wegwijzer der stad Gent, zoo voor Vremdelingen als voor de Inwoonders der selve stad, Gent, 1780-1839. F. - H. D'HOOP, La famille Van Alstein, ses ascendants, descendants et leurs allies, Gand, Vandermeulen frères, 1891, 336 p. F.V. GOETHALS, Dictionnaire généalogique et héraldique des familles nobles du royaume de Belgique, Bruxelles, PolackDuvivier, I, 1849, 750 p. ; II, 1849, 887 p. ; III, 1850, 914 p. ; IV, 1852, 1178 p. G. VAN HOOREBEKE, Le nobiliaire de Gand ou fragments généalogiques de quelques familles nobles qui ont résidé ou qui résident encore en cette ville, Gand, A. I. Vander Schelden, 1849, XIII + 215 p.

9 H. BALTHAZAR, Structuren en mutaties .... II, p. 366.

10 T. VAN LANDEGEM, Van het "ancien régime" naar de nieuwe tijd, ook te Beveren, in Het Land van Beveren, IV, 1961, 4, p. 127.
} 


\section{DE NOTABELEN VAN HET SCHELDEDEPARTEMENT}

Het Scheldedepartement, dat een oppervlakte van een 350.000tal ha (jaar IX) beslaat, bestaat uit vier arrondissementen : Gent, Oudenaarde, Dendermonde en Sas-van-Gent. Deze tellen in 1800 respectievelijk 219.360, $135.145,180.689$ en 59.524 inwoners, samen goed voor 594.619 inwoners. In 1814 bedraagt het totale aantal inwoners 599.663. Deze stijging is belangrijker dan op het eerste gezicht lijkt : in de 594.619 zijn ook de inwoners van ZeeuwsVlaanderen begrepen. Het Scheldedepartement is sen van de dichtsbevolkte gebieden van Europa; ca. 1796 wonen er gemiddeld 58 inw./km2.

Gent is en blijft met 55.161 inwoners in 1800 en 58.100 inwoners in 1814 het belangrijkste centrum van het departement. In het Land van Waas bekleedt Lokeren de eerste plaats (1800 : 11.941 inw., 1814 : 12.864 inw.), gevolgd door St.-Niklaas (1800 : 10.890, 1814 : 11.510). De getalsterkte van Lokeren wordt het dichtst benaderd door Aalst (1800 : 10.927, 1814 : 12.151). Ronse komt in de buurt van de 10.000 . Te Geraardsbergen stijgt de bevolking van bijna 6.000 in 1800 tot nagenoeg 6.600 in 1814, al blijft zij lager dan in de landelijke centra als Evergem (bijna 7.000 inw. in 1814) en vooral Hamme en Zele met elk ruim 8.000 inw. (in 1814). Die centra overtreffen ook de bevolking van de stad Eeklo (1814 : 6.269 inw.). Oudenaarde telt in 1800 4.267, en in 18145.048 inw., Dendermonde telt respectievelijk 5.028 en 5.796 inw.. Laatstgenoemden komen daarmee op ongeveer gelijke voet te staan met landelijke agglomeraties als Beveren, Kruishoutem. Nog veel geringer in aantal zijn Ninove (1814: 3.315$)$ en Deinze (1814: 2.901) die wat inwoneraantal betreft door vele dorpen van het departement voorbijgestreefd worden ${ }^{11}$.

Onderwerp van deze studie vormen dus een honderdtal notabelen uit het Scheldepartement. Het geografisch kader kan echter in grote mate gereduceerd worden tot het Gentse. Althans wat betreft de domicilie van de studieobjecten. Hier noteren we immers een uitgesproken overwicht van het arrondissement Gent, wat neerkomt op de Arteveldestad. Naarmate het Keizerrijk vordert, boet de hoofdstad van het Scheldedepartement aan belang in. Nieuwe centra (Oudenaarde, Dendermonde, Geraardsbergen, St.-Niklaas)

11 H. COPPEJANS-DESMEDT, J. HUYGHEBAERT, Het culturele leven in onze provincies onder Frans bewind. Het departement van de Schelde, in Gemeentekrediet van Belgiè. Driemaandelijks Tijdschrift, XLII, 1988, 164, p. 55-57. H. ROTTIER, Toegepast regionalisme in het departement van de Schelde, in Jaarboek Oudheidkundige Kring "De Vier Ambachten", 1970-1971, p. 20, 29. G. FAIPOULT, Mémoire Statistique du département de l'Escaut, ingeleid door Dr. Paul Deprez, Gent, Oostvlaams Verbond van de Kringen voor Geschiedenis, 1960, p. 37-46, 149 (Documenten, III). 


\section{CONNY DEVOLDER}

tekenen zich af. Een minderheid van de notabelen woont in 'niet-stedelijke gebieden'. Onderhavig cijfermateriaal kan ધén en ander verduidelijken...

\section{Het belang van de voornaamste stedelijke centra.}

Hieronder verstaan we de centra die in het jaar VIII 5.000 of meer inwoners tellen ${ }^{12}$. Ook Oudenaarde - standplaats van de onderprefect van het gelijknamig arrondissement, tevens éen van de belangrijkste marktcentra van het departement, een stad die in het jaar VIII 4.267 inwoners telde en Beveren, een stad van 4.927 inwoners (jaar VIII), werden als voorname centra weerhouden. In onderstaande tabellen bekijken we de domicilie van de notabelen, ingeschreven op de 'Lijst van de 60' (eerste kolom), op de 'Lijst van de markante personen' (tweede kolom).

\begin{tabular}{|l|r|rl|}
\hline Domicilie & 1805 & $|r l|$ & \\
\hline Gent & 50 & 34 & \\
Kruishoutem & 0 & 1 & \\
Totaal 1ste arr. & $50 \quad(92 \%)$ & 35 & $(70 \%)$ \\
\hline Ronse & 0 & 1 & \\
Geraardsbergen & 0 & 2 & \\
Oudenaarde & 1 & 4 & \\
Totaal 2de arr. & $1 \quad(1 \%)$ & 7 & $(14 \%)$ \\
\hline Aalst & 1 & 1 & \\
St.-Niklaas & 0 & 2 & \\
Wetteren & 1 & 0 & \\
Dendermonde & 0 & 3 & \\
Beveren & 1 & 1 & \\
Totaal 3de arr. & 3 & 7 & $(14 \%)$ \\
\hline Eeklo & 0 & 1 & \\
Totaal 4de arr. & 0 & 1 & $(2 \%)$ \\
\hline Algemeen Totaal & $54 \quad(100 \%)$ & 50 & $(100 \%)$ \\
\hline
\end{tabular}

Aanvankelijk wonen 54 van de 60 notabelen $(90 \%)$ in een stad van enig belang. 50 notabelen zijn gedomicilieerd in de stad Gent. Zij vertegenwoordigen $83 \%$ van de op de lijst ingeschrevenen, $92 \%$ van de notabelen-stedelingen. 50 markante personen $(80 \%)$ wonen in een stad van enig belang. 34 notabelen wonen in de stad Gent. Zij zijn goed voor $55 \%$ van de ingeschrevenen, $68 \%$ van de stedelingen.

12 G. FAIPOULT, Mémoire Statistique..., p. 37-46. 


\section{DE NOTABELEN VAN HET SCHELDEDEPARTEMENT}

2. Het belang van de overige domicilies.

\begin{tabular}{|l|c|c|}
\hline Domicilie & 1805 & 1812 \\
\hline arr. Gent & 2 & 4 \\
arr. Oudenaarde & 2 & 3 \\
arr. Dendermonde & 1 & 1 \\
arr. Eeklo & 1 & 4 \\
Totaal & 6 & 12 \\
\hline
\end{tabular}

Globaal gezien verdubbelen de 'niet-stedelijke gebieden' hun aandeel. Vooral het arrondissement Eeklo gaat erop vooruit.

\section{Algemeen totaal.}

\begin{tabular}{|c|c|c|}
\hline Domicilie & 1805 & 1812 \\
\hline $\begin{array}{l}\text { arr. Gent } \\
\text { arr. Oudenaarde } \\
\text { arr. Dendermonde } \\
\text { arr. Eeklo } \\
\text { Totaal }\end{array}$ & $\begin{array}{rr}52 & (86 \%) \\
3 & (5 \%) \\
4 & (6 \%) \\
1 & (1 \%) \\
60 & (100 \%)\end{array}$ & $\begin{array}{rr}39 & (62 \%) \\
10 & (16 \%) \\
8 & (12 \%) \\
5 & (8 \%) \\
62 & (100 \%)\end{array}$ \\
\hline
\end{tabular}

Het arrondissement Gent boet dus een kwart in. Het zogenaamde 2de arrondissement verdrievoudigt zijn aandeel, het 3de verdubbelt het zijne. Het arrondissement Eeklo vervijfvoudigt zijn numeriek belang maar blijft een secundaire rol spelen.

Resten nog 5 notabelen die enkel voorkomen op de 'Lijst van de 30' of op de 'Lijst van de talenten'. Deze lijsten maken immers geen melding van de domicilie. Deze kan echter gedistilleerd worden uit tal van andere archieflijsten, waaruit blijkt dat allen verblijf houden in Gent, wat het Gentse overwicht nog versterkt.

Behoren de notabelen uit hoofde van geboorte tot wat later het Scheldedepartement zou heten ? Zeker de helft van hen werd in de stad Gent geboren. 8 op de 10 behoren qua origine tot het bestudeerde departement. 7 notabelen werden in het binnenland, doch buiten het Scheldedepartement geboren: 3 in het departement van de Leie (Pierre Beyts, Guillaume Mesdach en Charles Oudaert), 2 in het departement van de Dijle (Pierre Van Gobbelschroy en Philippe Van Overloop), Albert Fonson zag het levenslicht in Bergen (departement Jemappes), Joseph Van Ertborn in Antwerpen (departement Twee Neten). 


\section{CONNY DEVOLDER}

Acht notabelen zijn van Franse herkomst: André Bazenerye (onderprefect van Eeklo, 1803-1814), Blémont (regeringscommissaris bij de pas opgerichte departementale rechtbank (1796), bij diens afschaffing aangesteld tot voorzitter van de criminele rechtbank (1800-1810)), Romain Chatillon (ondervoorzitter van de rechtbank van eerste aanleg van Gent, 1800-1806), Claude Esmangart, (achtereenvolgens plaatsvervangend rechter (1806-1808), substituut van de keizerlijke procureur (1807-1810) en voorzitter (1809-1814) van de rechtbank van eerste aanleg van Gent, tevens lid van de algemene raad (1811-1814)), Pierre Gervaise (directeur van de (directe) belastingen, 18061814), Jean Méaulle (procureur-generaal bij de criminele rechtbank (VIII1810), regeringscommissaris bij het crimineel gerechtshof (IX-1804), crimineel procureur des keizers te Gent bij het Hof van Assissen en het Speciaal Gerechtshof van het departement (1811-1814), algemene raad (18021807)), Pierre Muguet (algemeen ontvanger van het Scheldedepartement (1801-1814), algemene raad (1812-1814)) en Pierre Tinel (secretaris-generaal van de prefectuur, 1803-1814).

\section{Fortuin, macht en aanzien van de notabelen.}

Uit ons onderzoek blijkt dat fortuin, macht en aanzien geconcentreerd zijn in handen van deze kleine, door verwantschap verbonden groep. Na de 18de brumaire steunt het absolute gezag van Frankrijk op de heerschappij van de aanzienlijken, gevormd door de rijke burgerij met grondbezit en industriële belangen en door de meewerkende adel. Tot die aanzienlijken behoort eveneens een bestuurlijke elite, civiel en militair personeel dat systematisch uit de besten wordt geselecteerd. In onderhavige hoofdstukken zullen we eén en ander toelichten.

\section{Socio-demografische gedragspatronen.}

Algemeen kunnen we stellen dat de door ons bestudeerde notabelen in de toenmalige sociale structuur een minieme fractie uitmaken. De geboren en getogen Gentenaars behoren van huize uit veelal tot de (oude) aristocratie of tot de (al dan niet geadelde) handels- en nijverheidsburgerij. Onder de overige notabelen tellen we een zeer gering percentage dat op een adellijke status kan bogen. Wel behoren ze ongetwijfeld tot de lokale oligarchie. De aard - zowel kwantitatief als kwalitatief - van het bronnenmateriaal conditioneert hier echter ten zeerste onze kennis.

Globaal gezien stammen de notabelen uit een gezin van 5 à 6 kinderen. Bijna de helft onder hen zijn anno 1805 [datum waarop de 'Lijst van de 60 ' wordt opgesteld] de oudst levende żoon van de kroost (berekingsbasis : 70 


\section{DE NOTABELEN VAN HET SCHELDEDEPARTEMENT}

notabelen). 8 op de 10 werden geboren gedurende de tijdsspanne 1740-1769. De levensverwachting bedraagt gemiddeld 70 jaar. Jacques de Naeyer wordt 90 jaar, Joseph Van Ertborn sterft reeds op zijn 45ste. Voor het einde van het Keizerrijk zijn minimum 18 (maximaal 33) notabelen overleden.

\begin{tabular}{|l|r|l|lr|}
\hline \multicolumn{3}{|c|}{ Geboortedata } & \multicolumn{3}{c|}{ Sterftedata } \\
\hline klassegrenzen & \multicolumn{1}{|l|}{ frequentie } & klassegrenzen & \multicolumn{1}{l|}{ frequentie } \\
\hline $1720-29$ & $3(2 \%)$ & $1800-09$ & $4(3 \%)$ \\
$1730-39$ & $3(2 \%)$ & $1810-19$ & $16(15 \%)$ \\
$1740-49$ & $17(16 \%)$ & $1820-29$ & $19(18 \%)$ \\
$1750-59$ & $28(26 \%)$ & $1830-39$ & $20(19 \%)$ \\
$1760-69$ & $39(37 \%)$ & $1840-49$ & $10(9 \%)$ \\
$1770-79$ & $7(6 \%)$ & $1850-59$ & 5 & $(4 \%)$ \\
$1780-89$ & $2(2 \%)$ & $1860-69$ & 1 & $(1 \%)$ \\
$1790-99$ & $1(1 \%)$ & Onbekend & $30(28 \%)$ \\
Onbekend & $5(4 \%)$ & Totaal & $105(100 \%)$ \\
Totaal & $105(100 \%)$ & & \\
\hline
\end{tabular}

Anno 1800 zijn de notabelen gemiddeld 42 jaar oud. Onze studieobjecten zijn dus eerder bezadigde heren. Hun houding tijdens het Napoleontisch bewind kan niet toegeschreven worden aan 'jeugdige overmoed'. De gemiddelde leeftijd van de personen, voorkomend op de 'Lijst van de 60' bedraagt (anno 1805) 51 jaar. Dit is meteen ook de gemiddelde leeftijd (anno 1812) van de personen, ingeschreven op de 'Lijst van de markante personen'. Het is dus evenmin zo dat een jonge, dynamische groep de oude garde aflost. Wel noteren we dat 7 van de 10 jongste notabelen voor het eerst van zich laten - horen op de meest recente lijst. Onder hen bemerken we J. Van Ertborn $\left({ }^{\circ} 1778\right.$, onderprefect te Oudenaarde (1809-1814)), P. Tinel $\left({ }^{\circ} 1781\right.$, secretarisgeneraal van de prefectuur (1803-1814)), P. Van Gobbelschroy $\left({ }^{\circ} 1787\right.$, onderprefect te Gent (1811-1813)) en A. Vanderhaeghen ( ${ }^{\circ} 1790$, anno 1812 auditeur, onderprefect te Bergen). De vier benjamins van de groep scheren dus reeds op jeugdige leeftijd de hoogste toppen.

Sommige notabelen - 31 om precies te zijn (of $30 \%$ ) - zijn uit hoofde van geboorte nauw met elkaar verwant. We stellen vader-zoonrelaties vast tussen Emmanuel en Joseph della Faille, Philibert en Armand Vanderhaeghen, Jean-Baptiste en Antoine Versmessen. Volgende broers zijn eveneens in ons lijstje opgenomen : Beyens Albert - Constantin, Clemmen François - Jean, de Draeck Gaspard - Louis, de Loose Jean - Pierre, de Potter Edouard - Louis, Rodriguez Charles - Emmanuel, Vanderhaeghen Jean Philibert (en Schamp Jean-Baptiste - Jean-Gilles). François de Thiennes en 


\section{CONNY DEVOLDER}

Louis Van Rockolfing zijn stiefbroers, net als Louis en Philippe Van den Hecke. Anderen verhouden zich tot elkaar als oom en neef : Augustin en Emmanuel Piers, Edouard en Joseph Van Alstein, Charles en Philippe Vilain XIIII. Jean-Baptiste-Jean de Ghellinck is een neef van Jean-Baptiste-Pierre de Ghellinck. We merken op dat laatstgenoemde categorieën voor uitbreiding vatbaar zijn : voor wat betreft de binding oom-neef en neven onderling, werden enkel de relaties tussen gelijknamige notabelen nagegaan.

41 notabelen zijn door huwelijken, aangegaan door henzelf, broers, zussen of kinderen, met elkaar gelieerd. Indien de door de notabelen - evenals de door hun broers en zussen - aangegane huwelijken ons een beeld schetsen van het milieu waarin voornoemden zijn opgegroeid, dan vervolledigen de huwelijken van hun kinderen de voorstelling. We krijgen immers een schets van de kring waarin onze notabelen zich bewegen, van de verdere ontwikkeling van hun status. Dat de huwelijken eventueel na het Keizerrijk gesloten worden, is derhalve van secundair belang. Het blijkt dus dat fortuin, politieke, administratieve en rechterlijke macht (infra), ... geconcentreerd zijn in handen van een kleine, door verwantschap verbonden groep, waarbij we dan nog vriendschapsbanden moeten voegen.

Bekijken we het huwelijksleven van de notabelen van dichterbij. Vooraf weze gezegd dat we een doorsnede maakten voor het jaar 1813, en wel om volgende reden. In een niet gering aantal gevallen weten we niet wanneer de echtgenote overlijdt. Voor het jaar 1813 beschikken we echter over de lijsten van de gardes d'honneur. Deze bevatten indicaties over de burgelijke staat. Daar vele notabelen op deze lijsten ingeschreven werden, beschikken we over een zeer bruikbare bron, wiens gegevens daarenboven vergeleken kunnen worden met deze van de 'Lijst van de markante personen' (dd. 1812).

8 op de 10 notabelen treden voor of in de loop van voornoemd jaar in het huwelijk. Eén vijfde van de gehuwde notabelen is weduwnaar. De meeste notabelen trouwen op hun 27ste, hun bruid is 23 jaar (modus). De gemiddelde leeftijd bij het huwelijk bedraagt voor de notabelen 30 jaar, voor hun echtgenotes 23 jaar. Joseph Van Alstein trouwt reeds op zijn 18de, François Van Doorslaer pas op zijn 54ste. De bruid van Gaspard de Draeck is amper 16 jaar oud, de echtgenote van Alexandre de Baillet telt reeds 39 lentes. Emmanuel Blondel, Thomas Danneels, Emmanuel de Gage en François Van Doorslaer huwen een weduwe. Louis de Potter en Jean-Baptiste Soenens hertrouwen. Na het Keizerrijk zullen ook François Clemmen en Charles de Vaernewyck voor een tweede keer in het huwelijksbootje stappen. Charles Vilain XIIII trouwt een gescheiden vrouw. 


\section{DE NOTABELEN VAN HET SCHELDEDEPARTEMENT}

Globaal gezien bevestigen of versterken de notabelen door hun huwelijk hun maatschappelijke positie. Emmanuel della Faille bijvoorbeeld geeft grif toe dat zijn echtgenote meer in het huwelijk heeft ingebracht dan hijzelf. De notabelen, gesproten uit de rijke burgerij, vormen echter een interessanter onderzoeksvoorwerp. Zo zien we dat zowel Jean-Baptiste als Jean-Gilles Schamp huwelijken sluiten met afstammelingen van én van de oudste adellijke families van Vlaanderen (de Vaernewyck). Indien het niet tot een huwelijk komt met rasechte adel, zorgt men tenminste voor een huwelijk in gelijke stand. Getuige hiervan Pierre de Loose. Hij trouwt met Jeanne de Potter, dochter van een linnennegociant. Zoals op elke regel zijn er ook hier uitzonderingen. François Clemmen bijvoorbeeld huwt Colette Tricot, dochter van een minder bekende bankier. Tot slot vermelden we het geval Tinel. Deze geneesheer, loot van 'een oude en goede familie' uit Montpellier, wordt anno 1803 benoemd tot secretaris-generaal van de prefectuur. In 1811 wordt hij door zijn huwelijk met Marie-Thérèse Papeleu opgenomen in een rijke, in Gent zeer gewaardeerde familie. Een ambtenaar noteert : "La position $d u$ titulaire [P. Tinel] n'a éprouvé de changement notable depuis son entrée dans la carrière administrative, autre que celui qui est résulté de son mariage (....)".

$11 \%$ van de notabelen is vrijgezel, $15 \%$ heeft een kinderloos gezin. 33 $\%$ heeft én of twee kinderen. Deze drie categoriežn vertegenwoordigen $59 \%$ van de totaliteit.

\begin{tabular}{|c|rc|}
\hline Aantal kinderen & \multicolumn{2}{|c|}{ Aantal gezinnen } \\
\hline 0 & 11 & $(15 \%)$ \\
1 & 13 & $(18 \%)$ \\
2 & 11 & $(15 \%)$ \\
3 & 10 & $(14 \%)$ \\
4 & 10 & $(14 \%)$ \\
5 & 8 & $(11 \%)$ \\
6 & 3 & $(4 \%)$ \\
7 & 2 & $(3 \%)$ \\
8 & 2 & $(3 \%)$ \\
9 & 1 & $(1 \%)$ \\
Totaal & 71 & $(100 \%)$ \\
\hline
\end{tabular}

De modus is 1 . De meeste gehuwde notabelen hebben anno 1813 én (in levend zijnd, al dan niet gehuwd) kind. Drie op de vier heeft een gezin van 0 a 4 kinderen. De mediaan is 3. Laten we de gehuwde notabelen zonder kinderen buiten beschouwing, dan komen we tot een mediaan met waarde 4 .

13 We bestudeerden 71 notabelen of $80 \%$ van de gehuwde notabelen. 


\section{CONNY DEVOLDER}

\begin{tabular}{|c|c|rr|}
\hline Aantal kinderen & Klassemidden & \multicolumn{2}{|c|}{ Aantal gezinnen } \\
\hline $0-2$ & 1 & 35 & $(49 \%)$ \\
$3-5$ & 4 & 28 & $(39 \%)$ \\
$6-8$ & 7 & 7 & $(10 \%)$ \\
$9-11$ & 10 & 1 & $(1 \%)$ \\
Totaal & & $71(100 \%)$ \\
\hline
\end{tabular}

De resultaten van ons demografisch onderzoek stemmen dus overeen met de besluiten van F.G.C. Beterams in zijn werk over de notabelenlijsten van de jaren 1814-1815: "(...) ne jouissant que de quelque argent de poche, dont le montant dépendait de la parcimonie ou de la générosité paternelles, cette jeunesse se trouvait dans l'impossibilité de fonder un foyer, même d'y songer, avant d'avoir pris la succession, c'est-d-dire vers ou dans la trentaine, l'áge idéal pour le mariage, aussi bien pour cette classe privilégée que pour les autres couches de la sociéte, puisqu'une union tardive réduirait forcément la possibilité d'une progéniture encombrante. Le bien-fondé de ce raisonnement apparaît clairement de la lecture d'un tableau suggestif: les célibataires, les époux sans enfants, les mariages avec un ou deux enfants représentent plus de $60 \%$ de cette société. Pareille tactique préservera la fortune d'un morcellement régulier, entraînant l'apprauvissement inévitable ou la déchéance pour certains rejetons." 14.

Beschouwen we de adellijke status van de notabelen. 52 notabelen (of $58 \%$ ) genieten tijdens de Oostenrijkse periode een adellijke status. 29 onder hen kunnen zich laten voorstaan op een adellijke titel. De resterende 33 behoren tot de niet-getitelde adel. In deze categorie treffen we enkele geadelde negocianten aan (Jacques de Naeyer, Jean-Baptiste en Jean-Gilles Schamp...). Bij decreet van 19 juni 1790 worden feodale kwalifikaties en adellijke titels opgeheven. Na 1800 verzwakken de door de revolutionairen gepropageerde democratische opvattingen. Leden van de oude adel en van de hogere stedelijke burgerij worden opgenomen in het Erelegioen en de Keizerlijke adel.

De wet betreffende de oprichting van het Legioen van Eer wordt op 19 mei 1802 door de Eerste Consul afgekondigd. Militairen kunnen in het Legioen opgenomen worden omwille van oorlogsdaden of wegens bewezen diensten in vredestijd. Burgers die grote diensten aan de Staat bewezen hebben, kunnen eveneens lid worden. Bij keizerlijk decreet van 1 maart 1808

14 F.G.C. BETERAMS, The high Society Belgo-Luxembourgeoise (avec celle des arrondissements de Bréda, de Maestricht et de Ruremonde) au début du Gouvernement de Guillaume ler, roi des Pays-Bas (1814-1815), Wetteren, Cultura, 1973, p. XI. 


\section{DE NOTABELEN VAN HET SCHELDEDEPARTEMENT}

schept Napoleon zijn nieuwe adel. De leden van het Legioen van Eer dragen de titel van ridder van het Keizerrijk. Een opname in het Legioen betekent een verheffing in de adelstand. Men kan niet verheven worden in de adel van het Keizerrijk zonder voorafgaande opname in het Erelegioen ${ }^{15}$.

Tijdens de Napoleontische periode worden 18 notabelen (of $17 \%$ ) opgenomen in de Keizerlijke adel. Vier onder hen worden vereremerkt met de titel van baron : Pierre de Meulenaere (wetgever, 1803-1814), Pierre Muguet (algemeen ontvanger van het Scheldedepartement (1801-1814) en lid van de algemene raad (1812-1814)), Jean Vanderhaeghen (lid van de prefectuurraad (1808-1811) en burgemeester van Gent (1811-1814)), Philibert Vanderhaeghen (lid van de algemene raad, 1800-1814) en Joseph Van Ertborn (anno 1802 opgenomen in de algemene raad van het departement van de Twee Neten, tevens onderprefect van Oudenaarde (1809-1814)). Philippe Vilain XIIII, lid van de algemene raad vanaf 1804 tot het einde van de Franse Tijd en gedurende twee maanden burgemeester van Gent (1808), wordt de 30ste juni 1811 graaf van het Keizerrijk. Voor elf notabelen was de verheffing in de adelstand een unicum : tijdens de Oostenrijkse Tijd behoorden ze niet tot de adel.

Anno 1803 wordt Charles Van Hulthem lid en adjunct-beheerder van de 'Société pour l'encouragement de l'industrie nationale' te Parijs. Hij behartigt er de belangen van de Gentse industriělen, in het bijzonder van zijn vriend Liévin Bauwens. Bonaparte hecht groot belang aan deze instelling, neemt al haar leden - dus ook Van Hulthem, op in het Erelegioen. In de hoedanigheid van luitenant-kolonel van de erewacht, escorteert voornoemde Bauwens de keizer bij zijn bezoek aan Gent (1810). Napoleon bezoekt diens fabrieken, neemt de gewezen burgemeester (1800-1801) en raadsheer bij de algemene raad (1801-1808) op in het Legioen van Eer. In 1809 zetten de Engelsen voet aan wal op Walcheren. Vanuit het Land van Waas organiseren de Fransen de verdediging van Antwerpen. Sint-Niklaas is het verzamelpunt van de 'gardes nationales', artillerie, ruiterij, foerage. Burgemeester Brusselman wordt opgenomen in het Erelegioen. Jacques Risseeuw wordt anno 1798 benoemd tot voorzitter van de municipale administratie van het kanton Oostburg. Twee jaar later wordt hij opgenomen in de arrondissementsraad. Hij draagt de

15 H. COPPEJANS-DESMEDT, J. HUYGHEBAERT, Het culturele leven.... p. 55. Liste générale des familles nobles, légalement reconnues en Belgique, Anvers, C. Van Merlen, 1856, p. I-II. De erfenis van de Franse Revolutie 1794 - 1814, tentoonstellingscatalogus (A.S.L.K., 17 maart - 11 juni 1989), p. 224-225. M. BERGE, La création de la légion d'Honneur et la noblesse imperiale en Belgique, in Revue nationale, XXVI, 1954, 250, p. 363. Annuaire de la Noblesse de la Belgique, Bruxelles, Librairie Polytechnique de decq et duhent, 1874, p. 321-329. 


\section{CONNY DEVOLDER}

burgemeesterssjerp van Oostburg (1801) tot zijn benoeming tot vrederechter van het gelijknamig kanton (1805). De diensten die Risseeuw tijdens de Revolutie heeft bewezen, zijn niet aflatende ijver bij het waarnemen van (onbezoldigde) administratieve posten, de genoten waardering, dit alles draagt ongetwijfeld bij tot zijn opname in het Erelegioen. Ook Alexandre De Vos, getypeerd als een excellente onderprefect (Dendermonde, 1800-1814), evenals Henri Van Raeden, 'een ijverig en toegewijd functionaris' (burgemeester van Hulst van 1808 tot het einde van het Keizerrijk, lid van de algemene raad vanaf 1812) en François de Naeyer, de toegewijde doch onbekwame Gentse burgemeester (1801) die weggepromoveerd wordt naar de prefectuurraad (18031814), worden gedecoreerd. Parijs is zo tevreden over het beheer van de Gentse burgemeester Joseph della Faille (1804-1808) dat deze aangesteld wordt tot officier en schatbewaarder van de derde cohorte van het Erelegioen. Louis de Potter en Jean Vanderhaeghen wonen de doopplechtigheid van de koning van Rome bij (1811). Beiden worden opgenomen in het Erelegioen. Norbert Van Aken en Charles de Vaernewyck, eveneens uitverkoren om deel uit te maken van de deputatie, geraken niet in Parijs, worden geen ster opgespeld...

\section{Fortuin.}

Voor vele notabelen betekent de Franse Revolutie een financiële aderlating. We zullen achtereenvolgens de quotisatie in de militaire contributie van 1794 en deze in de gedwongen lening van het jaar IV behandelen. Anderzijds opent de verkoop van nationale goederen nieuwe perspectieven : de domeingoederen worden immers aan zowat de helft van hun feitelijke waarde geveild. Ook vanuit een andere gezichtshoek biedt het koopgedrag van de notabelen een interessant onderzoeksthema : het kan een meter zijn van hun verkleefdheid aan het revolutionair regime, van hun gehechtheid aan de Republiek (die ze met hun verwervingen moreel en financieel onder- steunen), van hun vertrouwen in de duurzaamheid van de hervormingen, in het onaantastbaar bezit van de aankopen ${ }^{16}$.

Anno 1794 belast de Franse Republiek de Belgische steden met een zeer hoge oorlogsschatting. Bij besluit van de Franse vertegenwoordiger Laurent dd. 3 fructidor II (22-8-1794), wordt het aandeel van Gent bepaald op 7 miljoen livres. De stadsmagistraat zal deze belasting omslaan over de clerus, de adel, de geprivilegieerden, de grote eigenaars en de rijken. De schattingen moeten binnen een korte termijn afgelost worden; in geval van vertraging zal

16 J. LAMBERT, De verkoop van nationale goederen in het departement van de Schelde, 1796-1814, en in de provincie Oost-Vlaanderen, 1820-1821, Gent, R.U.G. (onuitgegeven doctoraatsverhandeling), 1960, p. 191, 221, 370. 


\section{DE NOTABELEN VAN HET SCHELDEDEPARTEMENT}

men gijzelaars nemen ${ }^{17}$. Deze noodmaatregel wordt effectief uitgevoerd : Eugène Van Hoobrouck en Charles Van Hulthem moesten het aan den lijve ondervinden. Minimum 48 van de door ons bestudeerde notabelen worden aangeslagen. $\mathrm{Zij}$ vertegenwoordigen $46 \%$ van de proefgroep.

Het Directoire vaardigt de 19de frimaire IV (10-12-1795) een gedwongen lening uit die 600 miljoen livres moet opbrengen. Het aandeel van de Belgische departementen wordt op 40 miljoen bepaald, waarvan het Scheldedepartement er 8 moet inzamelen. De gedwongen lening viseert de gegoeden. Worden beschouwd als dusdanig : het vierde deel van de burgers van elk departement dat het meest belast of belastbaar is. Het opstellen van de rollen gaat gepaard met vrij veel vergissingen. Hoe dan ook, het voorkomen van een notabele op de rollen van de gedwongen lening getuigt van een zekere inkomensstatus ${ }^{18}$. Minimum 43 notabelen (of $41 \%$ ) worden geviseerd.

Het bestuur van het Scheldedepartement veilt in de periode 1796-1813 27.079 ha nationale goederen ${ }^{19} .46$ notabelen verwerven zwarte goederen. $\mathrm{Zij}$ vertegenwoordigen $44 \%$ van de bestudeerde groep. 6 op de 10 zijn 'grote kopers' : ze verwerven 20 ha of meer. Onderhavige tabel geeft een overzicht van de kopers van nationale goederen, verdeeld naar verworven bezit.

17 H. BALTHAZAR, Structuren en mutaties..., II, p. 310. S. VERVAECK, Enkele bronnen uit de Franse tijd. Hun belang voor de sociale geschiedenis, Leuven/Parijs, Editions Nauwelaerts/Béatrice Nauwelaerts, 1962, p. 5 (Bijdragen van het Interuniversitair Centrum voor hedendaagse geschiedenis, XXII).

18 H. BALTHAZAR, Structuren en mutaties..., II, p. 325-331. S. VERVAECK, Enkele bronnen..., p. 19-27.

19 J. LAMBERT, De verkoop van nationale goederen..., p. 365. 


\section{CONNY DEVOLDER}

\begin{tabular}{|rl|cc|}
\hline \multicolumn{2}{|c|}{ Aantal notabelen } & \multicolumn{2}{|c|}{ Aantal notabelen } \\
\hline $2250 \mathrm{ha}$ & 4 & $(9 \%)$ \\
200 & $-<250 \mathrm{ha}$ & 0 & $(0 \%)$ \\
150 & $-<200 \mathrm{ha}$ & 2 & $(4 \%)$ \\
100 & $-<150 \mathrm{ha}$ & 2 & $(4 \%)$ \\
50 & $-<100 \mathrm{ha}$ & 10 & $(22 \%)$ \\
20 & $-<50 \mathrm{ha}$ & 9 & $(20 \%)$ \\
0 & $-<20 \mathrm{ha}$ & 18 & $(40 \%)$ \\
Onbekend & & 1 & $(2 \%)$ \\
Totaal & & 46 & $(100 \%) \quad 20$ \\
\hline
\end{tabular}

Constant Hopsomere, Philippe Van den Hecke, Philippe Van Overloop, Charles Oudaert en François Ottevaere zijn de onbetwiste nummers én. Hopsomere komt met 686 ha (1796-1798) vooraan op de lijst. Zijn naam bekleedt op 21-8-1796 de allereerste plaats van de kopers. Als voorzitter van de centrale administratie van het Scheldedepartement geeft hij bijgevolg voortreffelijk de toon aan. Van den Hecke verwerft 643 ha (1797-1813), Van Overloop 301 ha (1798-1812), Oudaert 252 ha (1797-1811) en Ottevaere naast er 193 (1797-1803).

Ca. $84 \%$ van de verworven oppervlakte wordt vo6r het Concordaat gekocht. De notabelen kopen dus veel meer voor dan na het Concordaat. Vooral in de aanvangsperiode naasten ze zich nationale goederen toe. Het is tijdens deze periode - die algemeen bekend staat als de belangrijkste verkooptijd - dat de godsdienstige crisis zich het scherpst aftekent. De betekenis van het vredebrengend verdrag ligt vervat in het feit dat het de koper het blijvend bezit van de verworven goederen verzekert en dat het het geweten van de verwervers van de overblijvende $18 \%$ kan sussen ${ }^{21}$.

Conform aan de wet van 13 ventôse IX (4-3-1801) die voorziet in de vorming en vernieuwing van de kiezerslijsten, worden er anno 1801 gemeentelijke, departementale en nationale notabiliteitslijsten opgesteld. De

20 Ter vergelijking : het aantal kopers van meer dan 150 ha, wonende in het Scheldedepartement, geestelijken uitgezonderd :

kopers van meer dan 250 ha: 6

200 tot 250 ha : 3

150 tot 200 ha : 6

totaal : 15 (J. LAMBERT, Inbeslagname en verkoop van de nationale goederen, in Handelingen van de Maatschappij voor Geschiedenis en Oudheidkunde te Gent, Nieuwe Reeks, XIV, 1960, p. 196). 374.

21 J. LAMBERT, De verkoop van de nationale goederen..., p. 112-114, 


\section{DE NOTABELEN VAN HET SCHELDEDEPARTEMENT}

notabelen die deel uitmaken van de gemeentelijke lijst, duiden én tiende uit hun midden aan om de departementale notabiliteitslijst te vormen. Evenzo duiden de notabelen die deel uitmaken van de departementale lijst é́n tiende uit hun midden aan om de nationale lijst te vormen. De senaat duidt uit die nationale notabelen de leden van het tribunaat en het wetgevend lichaam aan. De lijst van de notabelen van het Scheldedepartement, verkozen om op de nationale notabiliteitslijst te staan, bevat in totaal 98 personen ${ }^{22}$. 73 notabelen (70\% van de bestudeerde groep) prijken op de lijst van de gemeentelijke notabelen (waarvan $70 \%$ op de lijst van het arrondissement Gent). 56 notabelen figureren op de departementale notabiliteitslijst, 30 op de nationale.

$\mathrm{Na} 1800$ verzwakken de door de revolutionairen gepropageerde democratische opvattingen. De maatschappij krijgt een censitair karakter. Enkel zij die cijns betalen, hebben stemrecht, nemen deel aan het bestuur en genieten de gunst van Napoleon. Of nog anders gezegd : de criteria waarop kiezers en ambtenaren worden geselecteerd, zijn aanzien en bezit ${ }^{23}$. De lijsten van de belangrijkste eigenaars, van de $(600,100,60,30, \ldots)$ meest belasten, van de markante personaliteiten - lijsten waarop we tal van notabelen terugvinden - zijn dus niet enkel en alleen te beschouwen als een loutere, vrijblijvende indicator van de fortuinstoestand van de bestudeerde notabelen. Ter illustratie halen we twee voorbeelden aan.

François de Naeyer, anno 1801 benoemd tot burgemeester van Gent, blijkt niet in staat een stad van dergelijk belang te representeren. De prefect kijkt uit naar een geschikte opvolger en draagt half oktober 1803, in een schrijven aan de minister van binnenlandse zaken, Eugène Van Hoobrouck voor. Deze notabele werd weliswaar bereid gevonden het burgemeestersambt op te nemen, doch hij figureert niet op één van de vier kantonnale lijsten van de 100 meest belasten van de stad Gent : hij betaalt zijn belastingen in Moregem. Het senatus-consulte van 16 thermidor $\mathrm{X}$ bepaalt dat de kandidaten

22 RAG, $F S d, 3095 / 54$, Nationale verkiezingen van het jaar IX. Lijst van de notabelen van het Scheldedepartement, verkozen om op de nationale notabiliteitslijst te staan, conform aan de wet van 13 ventose IX die voorziet in de vorming en vernieuwing van de kiezerslijsten, 1 frimaire $X$. AN, F IcIII Escaut 1, De minister van binnenlandse zaken aan de prefect van het Scheldedepartement, 21 floréal IX. P. POULLET, Les Institutions Françaises de 1795 a 1814. Essai sur les origines des Institutions Belges contemporaines, Bruxelles, Librairie Albert Dewit, 1907, p. 466. L. FRANCOIS, Elite en gezag. Analyse van de Belgische elite in haar relatie tot de politieke regimewisselingen, 1785-1835, Gent, R.U.G. (onuitgegeven doctoraatsverhandeling), 1987, I, p. 300.

23 L. FRANCOIS, Elite en Gezag..., II, p. 859. H. COPPEJANSDESMEDT, J. HUYGHEBAERT, Het culturele leven..., p. 55. 


\section{CONNY DEVOLDER}

voor de gemeenteraad gekozen moeten worden onder diegenen die deel uitmaken van de lijst van de 100 hoogst aangeslagenen van het kanton ${ }^{24}$. "Je suis faché de cette circonstance; car M. De Mooregem est extrement recommandable par ses talens et par d'excellentes qualites" aldus Faipoult, die ten lange leste Joseph della Faille voordraagt. Nauwelijks enkele dagen later bericht hij dat deze kandidaat evenmin in aanmerking komt : della Faille geniet een wankele gezondheid, zijn 'gout de campagne' is onverenigbaar met het burgemeesterschap van Gent. Misschien kan men de Naeyer tot de algemene vernieuwing van de burgemeesters op post houden ? Een andere mogelijkheid bestaat erin hem te benoemen tot lid van de prefectuurraad, zonder evenwel te weten wie dan wel burgemeester mag worden. Binnenkort keert iedereen naar de stad terug. Eenmaal de plaats vacant is zal het trouwens makkelijker zijn om de bereidheid van de aanbevelenswaardige notabelen te kennen. De 3de december wordt Van Hoobrouck opgenomen in de algemene departementsraad, de 26ste wordt de Naeyer benoemd tot lid van de prefectuurraad. Begin januari stelt de prefect voor een uitzondering op de bestaande wetgeving te maken en Van Hoobrouck alsnog tot burgemeester te benoemen. Daartoe blijkt Parijs niet bereid : half februari 1804 wordt della Faille benoemd.

Om lid te kunnen worden van het departementaal kiescollege, moet men figureren op de lijst van de 600 hoogst aangeslagenen. Dergelijke lijsten bestaan uit 50 personen, voorgedragen door de prefect (wegens hun functie of een speciale verdienste). De overige 550 worden geselecteerd uit een groep van $\mathbf{7 3 0}$ die allen aan de voorwaarden voldoen. Aldus kunnen rijke politieke tegenstanders volkomen legaal geweerd worden. De leden van het college worden aangeduid door de kantonnale vergaderingen. De Eerste Consul kan aan het departementaal kiescollege 20 personen toevoegen. Het betreft hier 10 personen die op de lijst van de 30 meest belasten van het departement prijken, en 10 anderen die deel uitmaken van het Erelegioen, of die bijzondere diensten hebben bewezen. De leden van de kiescolleges (arrondissementele zowel als departementale) worden benoemd voor het leven. Het lidmaatschap van een arrondissementeel kiescollege is onverenigbaar met dat van het departementaal kiescollege 25.59 notabelen (of $57 \%$ ) doen vroeg of laat (ten gevolge van de verkiezingen van het jaar XI, 1807 of 1812) hun intrede in het departementaal kiescollege. 28 notabelen zetelen vanaf het jaar XI onafgebroken (tot het einde van het Keizerrijk of tot hun overlijden) in voornoemd college. Albert Beyens' faillietverklaring betekent het einde van zijn lidmaatschap. 15

24 S. VERVAECK, Enkele bronnen..., p. 79. P. POULLET, Les institutions..., p. 776.

25 S. VERVAECK, Enkele bronnen..., p. 84-85. L. FRANCOIS, Elite en Gezag..., II, p. 879. P. POULLET, Les Institutions..., p. 544-553, 590-596. 


\section{DE NOTABELEN VAN HET SCHELDEDEPARTEMENT}

notabelen maken in het jaar XI deel uit van een arrondissementeel kiescollege maar worden anno 1807 afgevaardigd naar het departementaal kiescollege. 30 notabelen zetelen nooit of te nimmer in een kiescollege.

Bekijken we de lijst van de 60 meest vooraanstaande eigenaars van het Scheldedepartement (16-6-1805) van dichterbij. Onderhavige tabel geeft een overzicht van de notabelen, verdeeld naar belastingsbedrag :

\begin{tabular}{|c|cc|}
\hline $\begin{array}{c}\text { Belastingsbedrag } \\
\text { [Frank] }\end{array}$ & Aantal notabelen \\
\hline $3.000-<4.000$ & 2 & $(3 \%)$ \\
$4.000-<5.000$ & 1 & $(1 \%)$ \\
$5.000-<6.000$ & 6 & $(10 \%)$ \\
$6.000-<7.000$ & 7 & $(11 \%)$ \\
$7.000-<8.000$ & 0 & $(0 \%)$ \\
$8.000-<9.000$ & 15 & $(25 \%)$ \\
$9.000-<10.000$ & 9 & $(15 \%)$ \\
$10.000-<11.000$ & 9 & $(15 \%)$ \\
$11.000-<12.000$ & 1 & $(1 \%)$ \\
$12.000-<13.000$ & 4 & $(6 \%)$ \\
$13.000-<14.000$ & 1 & $(1 \%)$ \\
$14.000-<15.000$ & 1 & $(1 \%)$ \\
$15.000-<16.000$ & 2 & $(3 \%)$ \\
$16.000-<17.000$ & 1 & $(1 \%)$ \\
$17.000-<18.000$ & 0 & $(0 \%)$ \\
$18.000-<19.000$ & 0 & $(0 \%)$ \\
$19.000-<20.000$ & 1 & $(1 \%)$ \\
Totaal & $60 \quad(100 \%)$ \\
\hline
\end{tabular}

Uit de cumulatieve verdeling blijkt dat én op de twee notabelen voor minder dan $9.000 \mathrm{fr}$. aangeslagen wordt. Negen op de tien betalen nog geen 13.000 frank.

De lijst van de meest markante personen van het Scheldedepartement (197-1812) verstrekt ons volgende gegevens:

\section{RIJKSUNIVERSITEIT - GENT}

SEMINARIE VOOR ALGEMENE EN

INSTITUTIONELEE GESCHIEDENIS

DEF MIODELEEUWEN

Blandijnberg 2 - 9000 GENT 


\section{CONNY DEVOLDER}

\begin{tabular}{|c|rc|}
\hline $\begin{array}{c}\text { Inkomen } \\
\text { [frank] }\end{array}$ & \multicolumn{3}{|c|}{ Aantal notabelen } \\
\hline $0-<10.000$ & 16 & $(26 \%)$ \\
$10.000-<20.000$ & 12 & $(19 \%)$ \\
$20.000-<30.000$ & 13 & $(21 \%)$ \\
$30.000-<40.000$ & 9 & $(14 \%)$ \\
$40.000-<50.000$ & 0 & $(0 \%)$ \\
$50.000-<60.000$ & 2 & $(3 \%)$ \\
$60.000-<70.000$ & 6 & $(10 \%)$ \\
$70.000-<80.000$ & 0 & $(0 \%)$ \\
$80.000-<90.000$ & 1 & $(1 \%)$ \\
$90.000-<100.000$ & 1 & $(1 \%)$ \\
100.000 & 1 & $(1 \%)$ \\
Onbekend & 1 & $(1 \%)$ \\
Totaal & 62 & $(100 \%)$ \\
\hline
\end{tabular}

Uit de cumulatieve verdeling blijkt dat $45 \%$ een inkomen heeft van minder dan $20.000 \mathrm{fr}$. Acht op de tien notabelen heeft een inkomen dat de $\mathbf{4 0 . 0 0 0}$ grens niet overschrijdt. Beschouwen we de notabelen die enkel op de lijst van de markante personen voorkomen (die .a.w. op geen enkele andere basislijst figureren), dan komen we tot het besluit dat $41 \%$ een inkomen heeft van minder dan 10.000 frank, en dat het inkomen van $83 \%$ van de notabelen kleiner is dan 30.000 frank. Wanneer we de gegevens van de lijst van de markante personen aanvullen met deze van de lijst van de hoogst aangeslagenen van de stad Gent (15-5-1812), en aldus de berekeningsbasis optrekken tot 71 notabelen, dan komen we tot dezelfde conclusies (nl. $46 \%$ met een inkomen $<20.000$ frank en $82 \%<40.000$ frank).

Op het einde van het Keizerrijk worden de notabelen van elk departement opgeroepen om mee te werken aan de vorming van de gardes d'honneur. Deze regimenten moeten het leger bijstaan in de verdediging van het keizerrijk. Door op de vooraanstaanden een beroep te doen wil men de publieke opinie gunstig stemmen ${ }^{26} .71$ notabelen worden ingeschreven op de lijsten van de gardes d'honneur. Zij vertegenwoordigen $79 \%$ van de anno 1813 nog in leven zijnde notabelen. De cumulatieve verdeling naar inkomen levert resultaten op, gelijklopend aan die van voorgaande lijsten : $44 \%$ van de ingeschrevenen heeft een inkomen dat de 20.000 -grens niet overschrijdt, $81 \%$ verdient minder dan $\mathbf{5 0 . 0 0 0}$ frank. 


\section{DE NOTABELEN VAN HET SCHELDEDEPARTEMENT}

\section{Beroepsactiviteiten.}

Prefect Faipoult typeert onze contreien als een "pays riche et commerçant". P. Goetghebuer noteert over Jacques Van Caneghem : "Possesseur d'une immense fortune, qu'il devait tout entière d̀ son génie et d son activité personnelle (...)". De opsteller van de lijst van de 30 meest belasten schrijft bij François Ottevaere : "sa fortune est son ouvrage". Voor wie niet gespeend was van enige ondernemingszin, waren de tijdsomstandigheden inderdaad gunstig. Gedurende de periode 1735/45 - 1815 wordt de eeuwbeweging gekenmerkt door een hausse, van 1789 tot 1815 verkeren we in de opgaande fase van een Kondratieff. De Gentse suikernijverheid en de textielindustrie (katoendrukkerij) zijn twee nieuwe, kapitalistische nijverheden die onder de regering van Maria-Theresia een grote opbloei kennen. Het is precies in deze sectoren dat Guillaume Poelman, evenals François en Jean Clemmen, bedrijvig zijn. Tijdens Consulaat en Keizerrijk komt een tweede industrialiseringsfase tot bloei. Het is de tijd van Liévin Bauwens, de periode waarin Gent naar voor komt als pionier van de industriële revolutie op het Europese continent ${ }^{27}$.

Een kwart van de notabelen legt - al dan niet tijdens het Keizerrijk - enige economische bedrijvigheid aan de dag. Onder hen noteren we 7 negociantenfabrikanten, 17 negocianten en 2 bankiers. De negocianten zijn - enkele uitzonderingen daar gelaten - gedomicilieerd in de steden Gent, Aalst en Oudenaarde, de marktcentra van het departement. Jacques Risseeuw is bierbrouwer, Charles Bogaert zoutraffinadeur en tabakhandelaar. Guillaume De Clercq blijkt molenaar, olieslager en groothandelaar in granen, hop en olie. Hij bevoorraadt de Oostenrijkse en Franse troepen, doet leveranties aan de stad Aalst. De Clercq financiert een graantransport naar Jemappes en onderneemt verscheidene zakenreizen naar Holland. Hij heeft eveneens belangen in de scheepvaart op de Dender. François Ottevaere doet zeer grote

27 G. FAIPOULT, Mémoire statistique..., p. 12. P. J. GOETGHEBUER, Biographie gantoise, handschrift 19de eeuw, p. 125. RAG, $F$ Sd, 2219/1, Nottes sur les 30 plus imposés du département de l'Escaut, 18 vendémiaire -20 brumaire XII. H. BALTHAZAR, Sociaal-politieke ontwikkeling en financiele instellingen te Gent van 1780 tot 1850, Extrait de overheidsfinancién Ancien Regime - Hedendaagse Overheidsfinancièn in Belgie van 1740 tot 1860 . Mutatieproces - Continuilteit en onderbrekingen. Gemeentekrediet van Belgie, 1975, p. 352 (Historische Uitgaven Pro Civitate, XXXIX). H. COPPEJANSDESMEDT, Bijdrage tot de studie van de gegoede burgerij te Gent in de XVIII eeuw. De vorming van een nieuwe sociaal-economische stand ten tijde van Maria-Theresia, Brussel, Paleis der Academieĕn, 1952, p. 17, 189 (Verhandelingen van de Koninklijke Vlaamse Academie van Belgie,, Klasse der Letteren, XIV, $\left.n^{\circ} 17\right)$. H. COPPEJANS-DESMEDT, J. HUYGHEBAERT, Het culturele leven..., p. 55. 


\section{CONNY DEVOLDER}

leveranties aan de Fransen. Philippe Van Overloop wordt op het einde van de 18de eeuw aangeklaagd als leverancier van de Engelsen, doch de overheid hecht aan deze beschuldiging geen geloof. Anders vergaat het Jacques Van Caeneghem, die op verdenking van smokkelarij uit de algemene departementsraad ontslagen wordt (1807). Anno 1816 richt deze groothandelaar te Ledeberg een katoenspinnerij op. Hubert De Smet is groothandelaar in wijn en laken. Ghisbert Van Cazele verhandelt lijnwaad en wijn, Jean de Loose granen. In 1807 vraagt Mathieu Ketele een exploitatievergunning voor steenkool aan. De concessie wordt hem toegekend doch de ondergrond blijkt niet rijk genoeg om aan een uitbating te beginnen. Pierre Muguet staat bekend als agent van de bank van Frankrijk. Constant Hopsomere heet bankier, beheerder van twee verzekeringsmaatschappijen : de 'Societeyt der Assurantie' en de 'Vlaemsche Assurantie Societeyt' (in vennootschap met Pierre Hamelinck en de weduwe Van Aken, moeder van Norbert) en van het 'Comptoir van de Zee-Assurantie der stad Gend' (in associatie met Pierre Hamelinck en François Van Aken). Voornoemde N. Van Aken treedt op als negociant, reder. Hij is geassocieerd in de anno 1808 door zijn schoonbroer te Gent opgerichte katoenweverij 'Gréban et Compagnie'.

Eén op de twee notabelen oefent een intellectueel beroep uit (of is op zijn minst als dusdanig geschoold). Pierre Beyts, Pierre Tinel, Jean Vanderbeken en Pierre Verberckmoes zijn geneesheer. 46 notabelen zijn rechtsgeleerde. Wijzen we erop dat noch de geneesheren, noch de rechtsgeleerden kunnen wedijveren met de bankiers, reders, industriëlen en handelaars. Misschien is dit de drijfveer achter de economische activiteiten die een vijftal notabelenrechtsgeleerden aan de dag leggen. We hebben het hier meer bepaald over Thomas Danneels, Hubert De Smet, Albert Fonson, Jean Hoelands en Mathieu Ketele ${ }^{28}$.

Eén op de twee biedt de overheid (de Oostenrijkse, de Franse, de Hollandse of de Belgische) zijn diensten aan. Gedurende de periode 1800-1815 stelt de overheid 29 notabelen tewerk $(28 \%)$. De helft van de notabelenrechtsgeleerden maakt carrière in de magistratuur. Spitsen we onze aandacht toe op voornoemde periode, dan komen we tot een kleine $40 \%$, of 17 notabelen. Onder de 10 magistraten, verbonden aan de rechtbanken van eerste aanleg van het Scheldedepartement, tellen we vier voorzitters : Albert Beyens wordt anno 1800 benoemd tot voorzitter van de Gentse rechtbank van eerste aanleg. Eén maand na zijn faillietverklaring tekent hij zijn ontslag, Claude Esmangart volgt hem op (1809-1814). Ferdinand Eeman wordt anno 1800 benoemd te Dendermonde. In 1811 wordt hij (om redenen van onbekwaamheid ?) geretrogradeerd tot rechter. Mathieu Ketele zit van 1811

28 F.G.C. BETERAMS, The High Society..., p. X. 


\section{DE NOTABELEN VAN HET SCHELDEDEPARTEMENT}

tot 1817 de Oudenaardse rechtbank van eerste aanleg voor. Bernard Van Wambeke zit deze van Antwerpen voor (1809-1819). Romain Chatillon is ondervoorzitter te Gent (1800-1806). Weer anderen blijken vrederechter (Pierre de Blondel van het kanton Ninove, Jean Hoelands van Axel, Jacques Risseeuw van Oostburg, Isaac Tegelberg van Hulst, ...). Blémont en Jean Méaulle zijn verbonden aan de criminele rechtbank, evenals aan het Speciaal Gerechtshof en het Hof van Beroep.

Een kwart van de notabelen worden betrokken bij het financieel beheer. Tijdens de periode 1800-1815 tellen we er 16 (15\%). Maes is betaalmeester van het Scheldedepartement (1801-1814), Pierre Muguet algemeen ontvanger (1801-1814). Denis Papeleu staat bekend als ontvanger van de stad Gent (sinds 1785), Isaac Tegelberg als algemeen ontvanger van de polders. Pierre de Meulenaere is - evenals Jean-Baptiste d'Haene - (commissaris-)repartiteur van de grondbelasting van de stad Gent (1801-1812); voordien was hij commissaris van de huisgelden (1780-1794 : bediende bij het comptoir van de huisgelden), ontvanger van de twintigste penning, van het enregistrement. Pierre Gervaise blijkt speciaal commissaris voor de organisatie van de belastingen in België en Rome, directeur van de (directe) belastingen (18061814). Auguste Clavareau is achtereenvolgens directeur van de verenigde rechten (1808-1814), van de indirecte belastingen van het Scheldedepartement (1815), van de provincie Oost-Vlaanderen (1816-1820) en directeur van de inen uitgaande rechten en acsijnzen van Oost-Vlaanderen (1821-1824). Eugène Van Hoobrouck - gewezen thesaurier-generaal van de stad Gent (benoemd in 1778), tevens hoogpointer van de kasselrij Oudenaarde (1779), wordt in 1804 benoemd tot directeur van de verenigde rechten in Brugge. Vanaf 1798 wordt Albert Fonson betrokken bij het financieel beheer van het Oudenaardse. Niet alleen is hij actief als ontvanger van registratie en domeinen; vanaf 1801 is hij tevens bewaarder van hypotheken. Deze functies zal hij ook tijdens de Hollandse tijd uitoefenen.

Twaalf notabelen nemen de wapens op. Enkel Armand Vanderhaeghen dient tijdens het Keizerrijk in het leger (cavalerie-officier). Alexandre de Baillet begint zijn militaire loopbaan als vaandeldrager bij de fuseliers van de Waalse gardes (1765). Twee jaar later is hij vaandeldrager bij de grenadiers. Anno 1768 wordt hij gepromoveerd tot onderluitenant, om in 1776 luitenant te worden. In 1787 verlaat hij het leger; hij komt terug naar de Nederlanden om in Aalst de zuster van zijn schoonzuster te trouwen. Voor het uitbreken van de Franse Revolutie is Pierre de Blondel officier in Oostenrijkse dienst. Henri Van Raeden dient tot het jaar 1796 in het Hollands leger. Hij is meer bepaald kapitein van de cavalerie. Een andere keer wordt hij getypeerd als officier van de infanterie, als luitenant ter zee. Charles Vilain XIIII is 


\section{CONNY DEVOLDER}

infanterie-officier van Clerfayt. Tijdens de Brabantse Revolutie schaart hij zich als vrijwilliger aan de zijde van de patriotten. Vanaf het begin van november 1789 zet hij zich in om de opstandige beweging in NoordVlaanderen aan te wakkeren. Daartoe stelt hij zich in verbinding met Rens, gelastigde van het comité van Breda. Hij recruteert te Lokeren een honderdvijftigtal partizanen en opereert in het Land van Waas, evenals in de streken van Hulst. Vervolgens neemt Vilain XIIII deel aan de krijgsverrichtingen van majoor De Vaux tegen de stad Gent. Na de overwinning van de patriotten wordt hij adjudant van de graaf van Rosieres en kwartiermeester van generaal-majoor Koehler (leger van de Verenigde Belgische Staten). Anno 1790 wordt deze Vonckist gepromoveerd tot majoor. Tijdens de Oostenrijkse Restauratie zoekt Charles Vilain XIIII zijn toevlucht in het buitenland (Engeland ?). Hij staat bekend als auteur van geschiedkundige werken die de toenmalige militaire operaties behandelen.

\section{Politiek optreden.}

De notabelen spelen een politiek belangrijke rol. In de aan het jaar 1800 voorafgaande periode oefent meer dan de helft van hen $(56 \%)$ een politiek mandaat uit. Bekijken we enkel en alleen de Franse Tijd, dan komen we op een $33 \%$. De periode vo6r 1789 en de Oostenrijkse Restauraties scoren het hoogst. Tijdens eerstgenoemde periode zijn 34 notabelen (of $32 \%$ ) politiek actief, tijdens de Restauraties tellen we er 30.22 notabelen treden tijdens de Eerste Franse periode op de voorgrond, 27 tijdens Conventie/Directoire. Het is dus opvallend dat een tijd, die op institutioneel en economisch vlak zo vernieuwend is, in een niet onbelangrijke mate aanleunt bij sociale middens die reeds voor de Brabantse Omwenteling een vooraanstaande plaats bekleedden 29 .

We merken op dat $20 \%$ van de notabelen bij het naderen van de Franse troepen hun toevlucht zoeken in het buitenland. De drijfveren variëren van loutere angst tot manifeste trouw aan het Oostenrijkse goevernement. Het merendeel van de emigranten keert in de loop van juni-juli-augustus 1795 terug. Sommigen worden in het kader van de militaire contributie (Eugène Van Hoobrouck, Charles Van Hulthem), de Boerenkrijg (Jean de Kerchove, Joseph della Faille, Eugène Van Hoobrouck, Ignace Van Toers) of het 'Engels complot' (Bernard Van Wambeke) als gijzelaar weggevoerd.

Voor d'Hane de Steenhuyse verloopt de eerste kennismaking met het Franse regime allerminst goed : kort na de intocht van de Franse troepen in Gent belandt d'Hane - die algemeen bekend staat als behoudsgezind, wegens

29 cfr. H. BALTHAZAR, Structuren en mutaties..., II, p. 392. 


\section{DE NOTABELEN VAN HET SCHELDEDEPARTEMENT}

'hoogverraad tegen natie en vrijheid' in de gevangenis (november 1792). Tijdens de Oostenrijkse Restauratie houdt hij zich op het achterplan, bij de terugkomst van de Fransen emigreert hij naar de Verenigde Republiek, om in maart 1795 terug te keren. Het Directoire betekent een zware financiële dobber. d'Hane wordt bij elke belasting, ook bij de gedwongen lening, zwaar aangeslagen. Hij blijft echter in gebreke. $\mathrm{Na}$ de fructidoriaanse staatsgreep sluit regeringscommissaris Du Bosch hem op in een Parijse gevangenis. Na de Boerenkrijg herhaalt het scenario zich.

Niettemin evolueren notabelen als een d'Hane en Van Hoobrouck tot een soort aanvaarding van het regime : deze aristocraten, die tussen 1789 en 1815 optreden als conservatieve leiders, blijken tijdens Consulaat en Keizerrijk bereid tot het opnemen van politieke mandaten. Het regime beantwoordt wel niet aan alle verwachtingen, maar het is restaurerend genoeg om hen tot enige medewerking aan te zetten. Overtuigd van de soliditeit van het bewind spelen ze hun rol, erop rekenend dat dit hen en hun nageslacht ten goede zal komen. Joseph della Faille, schoonbroer van voornoemde d'Hane, verwoordt het als volgt : "on n'oublierait jamais le Monarque bienfaiteur d qui notre patrie doit tout, le retour d l'ordre, aux moeurs, aux sentiments religieux et d qui elle devra bientôt la paix et son ancienne splendeur."

Zes notabelen starten hun politieke carrière vớr 1789, en overleven alle regimewisselingen. Het zijn Constant Hopsomere, Guillaume Mesdach, Charles Oudaert, Emmanuel Piers, Philibert Vanderhaeghen en Jean-Baptiste Versmessen. Hopsomere en Piers behoren tot de groep die reeds van in den beginne onomwonden fransgezind is. Hopsomere wordt eind 1792 aangesteld tot Provisioneel Representant, Piers tot lid van de 26 Burgers. In juli 1794 maakt Hopsomere deel uit van de Commissie van Politie en Justitie, Piers van het Centraal Comite. Even later doet eerstgenoemde zijn intrede in de Municipaliteit van de 24ste messidor II. Zowel Hopsomere als Piers verblijven op de vooravond van de debatten in de Conventie over de vereniging met Frankrijk, in Parijs. Beiden zetelen achtereenvolgens in de administratie van het arrondissement Oost-Vlaanderen en de centrale administratie van het Scheldedepartement (Hopsomere : voorzitter (17951798), Piers : secretaris (1795-1797)). Allebei scharen ze zich aan de zijde van regeringscommissaris $\mathrm{Du}$ Bosch en prijken ze op de ledenlijst van de jacobijnse 'Cercle Constitutionnel' (1798). Met zijn 686 ha (1796-1798) is Hopsomere de grootste koper van nationale goederen, Piers verwerft 21 ha (1797-1800). Eerstgenoemde zetelt in de Raad der Ouden (1798-1799) en in het wetgevend lichaam (1799-1802). Piers wordt lid van de prefectuurraad (1800-1802). Beiden worden in het jaar XI afgevaardigd naar het departementaal kiescollege. 


\section{CONNY DEVOLDER}

Drie notabelen nemen tijdens de Eerste Franse Tijd voor het eerst een politiek mandaat waar : Bernard Van Wambeke, Norbert Van Aken en Pierre Beyts. Eind 1792 wordt Van Wambeke lid van de 26 Burgers, tijdens de Tweede Franse periode wordt hij opgenomen in de Commissie voor de Logementen (juli 1794) en aangeduid als secretaris van het Comite van de Keure. Vanaf december 1794 maakt Van Wambeke deel uit van de administratie van het arrondissement Oost-Vlaanderen. In november 1795 wordt hij benoemd tot lid van de centrale administratie van het Scheldedepartement. Hij zetelt er tot zijn benoeming tot hypotheekbewaarder te Gent (juni 1796-1799). In augustus 1799 volgt hij zijn tegenstander Du Bosch op als regeringscommissaris bij de centrale administratie. De staatsgreep van Brumaire maakt echter algauw een einde aan zijn mandaat. Bernard Van Wambeke wordt benoemd tot lid van de prefectuurraad (1800), blijft aan tot zijn opname in het wetgevend lichaam (1803-1807). Anno 1803 wordt hij aangesteld tot voorzitter van het kanton Gent-Noord, anno 1813 wordt zijn mandaat verlengd. Voornoemd kanton vaardigt hem af naar het departementaal kiescollege (jaar XI). Tot slot blijkt Van Wambeke substituut bij de Gentse (1809-1810) en voorzitter van de Antwerpse (1809-1819) rechtbank van eerste aanleg. Ook Van Aken zal nog van zich laten horen. Wel is hij bovenal koopman, net zoals Beyts' belangstelling in de eerste plaats academisch georiënteerd is (1801-1804 : professor aan de Centrale School van het Scheldedepartement, 1805-1811 : docent aan de Gentse School van Geneeskunde).

Zeven notabelen die gedurende de Tweede Franse Tijd een politieke functie uitoefenen, zijn nieuwkomers in het politieke firmament : Constantin Beyens is tijdens de Conventie magistraat van de stad en kasselrij Kortrijk. Anno 1796 wordt hij hoofd van de kantonnale administratie van Deinze. Emmanuel Blondel en Charles Bogaert blijken tijdens het Directoire lid van de municipale administratie van het kanton Geraardsbergen, Guillaume De Clercq zetelt in Aalst, Philippe Van Overloop in Gent. Ferdinand Eeman en Albert Fonson staan bekend als commissaris. Noteren we eveneens dat Van Overloop anno 1799 opgenomen wordt in de centrale administratie van het departement. Tijdens het Keizerrijk wordt Beyens onderprefect van het arrondissement Oudenaarde. De Clercq, Eeman, Fonson en Van Overloop doen hun intrede in een arrondissementsraad, Bogaert wordt opgenomen in de algemene departementsraad; allen, met uitzondering van Eeman, worden aangesteld tot voorzitter van een kantonnale vergadering.

$10 \%$ van de notabelen wordt tijdens de periode $1800-1815$ rechtstreeks betrokken bij de nationale politiek. Charles Van Hulthem wordt anno 1802 lid van het Tribunaat. Hij blijft aan tot de opheffing van dit orgaan (1808). 


\section{DE NOTABELEN VAN HET SCHELDEDEPARTEMENT}

Constant Hopsomere (1799-1802), Charles Oudaert (1803-1807), Bernard Van Wambeke (1803-1807), Pierre de Meulenaere (1803-1814), Joseph della Faille (1808-1814) en Louis de Potter (1808-1814) zetelen in het wetgevend lichaam. Geen enkele notabele wordt afgevaardigd naar de senaat. We tellen drie auditeurs : Armand Vanderhaeghen, Joseph Van Ertborn en Pierre Van Gobbelschroy.

$30 \%$ van de notabelen wordt benoemd in een functie op departementaal niveau. Onder de prefecten van het Scheldedepartement tellen we geen door ons bestudeerde notabelen. Deze functie werd voorbehouden voor Fransen als een Guillaume Faipoult (vanaf 1800), Frédéric d'Houdetot (vanaf 1808) en Bernard Desmousseaux (vanaf 1813). Pierre Tinel is van 1803 tot 1814 secretaris-generaal van de prefectuur. Als dusdanig is hij de rechterhand van de prefect. De prefectuurraad bestaat uit 5 personen. Emmanuel Piers wordt anno 1800 benoemd tot raadsheer. In 1802 dient hij, zich beroepend op een domicilieverandering (Brussel), zijn ontslag in. Louis de Potter volgt hem op, zetelt in de prefectuurraad tot zijn aanstelling tot wetgever (1808). Zijn plaats wordt ingenomen door Jean Vanderhaeghen, die in 1811 benoemd wordt tot burgemeester van Gent. Jacques Limnander volgt hem op, blijft aan tot 1814. Charles Oudaert wordt anno 1800 opgenomen in de prefectuurraad. Hij zetelt er tot zijn aanstelling tot wetgever (1803), wordt opgevolgd door Guillaume Mesdach die aanblijft tot 1814. Ook Bernard Van Wambeke wordt anno 1800 opgenomen in de raad, ook hij zetelt er tot zijn opname in het wetgevend lichaam (1803). François de Naeyer volgt hem op, zetelt er tot 1814. Anno 1800 volgt Norbert Van Aken Philippe Lippens - die bedankte voor de eer, op. Hij blijft raadsheer gedurende de hele Franse periode. De algemene departementsraad telt 24 leden. Hier nemen 22 notabelen zitting. Edouard Van Alstein weigert het mandaat op te nemen. Joseph Van Ertborn zetelt in de algemene raad van het departement van de Twee Neten ${ }^{30}$.

$15 \%$ wordt benoemd in een functie op arrondissementeel niveau. Onder de notabelen tellen we zes onderprefecten : André Bazenerye (Eeklo, 1803-1814), Alexandre De Vos (Dendermonde, 1800-1814), Constantin Beyens (Oudenaarde, 1800-1808), Joseph Van Ertborn die de overleden Beyens opvolgt (1809-1814), Pierre Van Gobbelschroy (in 1811 benoemd als eerste onderprefect van Gent, in 1813 overgeplaatst naar Deventer) en Armand Vanderhaeghen (Bergen, Leeuwarden). De arrondissementsraden bestaan uit 11 personen ${ }^{31}$. Evenzoveel notabelen nemen er zitting. Enkel Fostier,

\footnotetext{
30 P. POULLET, Les Institutions..., p. 760-768.

31 P. POULLET, Les Institutions..., p. 770-772.
} 


\section{CONNY DEVOLDER}

Vanderhaeghen en Van Doorslaer zijn zowel op het departementaal als op het arrondissementeel niveau actief.

Jean Fostier wordt anno 1802 benoemd tot lid van de raad van het arrondissement Oudenaarde. Zes jaar later wordt hij opgenomen in de algemene departementsraad. De prefect maakt hem er echter attent op dat voornoemd mandaat onverenigbaar is met het lidmaatschap van de arrondissementsraad. Fostier opteert voor de algemene raad, alwaar hij zetelt tot het einde van de Franse Tijd. François Van Doorslaer wordt anno 1804 benoemd tot lid van de arrondissementsraad van Gent, vier jaar later tot lid van de algemene departementsraad. In beide instellingen zetelt hij tot het einde van het Keizerrijk ! Jean Vanderhaeghen wordt eveneens in 1804 aangesteld tot lid van de raad van het eerste arrondissement, blijft aan tot het einde van het Keizerrijk. Van 1808 tot 1811 is hij raadslid van de prefectuur.

Vier op de tien notabelen engageren zich in de gemeentelijke politiek. Eén op de vijf wordt betrokken bij het beheer van de hoofdstad van het Scheldedepartement. Dertien notabelen zetelen in de Gentse gemeenteraad. de Thiennes, Van Cazele en Van Rockolfing weigeren dergelijk mandaat op te nemen. Ze beroepen zich op hun gevorderde leeftijd, hun wankele gezondheid, hun verlangen naar rust. Ook hun persoonlijke zaken eisen hun aandacht op. François Clemmen (1800-1804), François de Naeyer (1800-1801), Jacques Limnander (1802-1811) en Pierre de Loose (1804-1807) aanvaarden het mandaat van adjunct, de Vaernewyck weigert. Vijf notabelen dragen de burgemeesterssjerp.

Op een ogenblik dat velen afzien van een openbare functie, aanvaardt Liévin Bauwenș het burgemeesterschap van Gent waartoe de consul hem op 22 juni van het jaar 1800 heeft geroepen (Philibert Vanderhaeghen heeft immers bedankt voor de eer). Hij beperkt zich tot het uitvoeren van de regeringsbesluiten. Zijn ontslag, dat hij eind april 1801 indient - deels om gezondheidsredenen, maar ook en vooral omdat zijn economische activiteiten prioritair zijn, komt dan ook ongelegen. Begin augustus wordt François de Naeyer benoemd. Deze toegewijde doch onbekwame burgemeester wordt weggepromoveerd naar de prefectuurraad (december 1803) en opgevolgd door Joseph della Faille (februari 1804) die vier jaar later, wanneer hij benoemd wordt tot wetgever, zijn ontslag geeft. Philippe Vilain XIIII neemt de scepter over (april 1808), doch laat weten dat hij deze functie niet lang kan waarnemen. Hij beroept zich op het feit dat hij geen woning heeft te Gent; hij heeft er ook nooit zijn domicilie gehad. Zijn verblijf is een tiental mijl buiten de stad gelegen, temidden van zijn bezittingen, die al zijn aandacht opeisen. Daarenboven roepen persoonlijke zaken hem dikwijls buiten het 


\section{DE NOTABELEN VAN HET SCHELDEDEPARTEMENT}

departement. Mogelijks is dit niet meer dan een drogreden en dient de echte beweegreden gezocht in het proces dat tussen hem en het bureau van weldadigheid (bij wie hij - als zoon van de overleden grootbaljuw PhilippeMathieu Vilain XIIII - in het krijt staat) aanhangig is. Vilain XIIII draagt de sjerp amper twee maand. Zijn opvolger is Pierre-Joseph Pycke de ten Aerden. In februari 1811 volgt Jean Vanderhaeghen de tot prefect van het departement van de Mondingen van de Schelde benoemde Pycke op. Hij blijft aan tot februari 1814, datum waarop hij samen met de Franse functionarissen (waaronder de prefect) de stad verlaat.

Beschouwen we de andere steden en gemeenten, dan komen we tot de conclusie dat 31 notabelen er een municipale functie waarnemen. 26 notabelen dragen de burgemeesterssjerp. Acht onder hen staan aan het hoofd van én van de voorname centra van het departement : Charles Van der Meere (Kruishoutem, 1813-1825), Charles Bogaert (Geraardsbergen, 1808-1830), Mathieu Ketele (Oudenaarde, 1801-1811), Hubert De Smet (Oudenaarde, 1811-1813), Jean Brusselman (St.-Niklaas, 1808-1817), Charles Vilain XIIII (Wetteren, 1803-1808), Pierre Verberckmoes (Dendermonde, 1800-1814), Jean-Baptiste Everaert (Beveren, 1812-1854).

Niet weinigen beschouwen het burgemeesterschap als een logische voortzetting van het ambt van 'heer', dat zij zonder de Franse Revolutie geërfd zouden hebben. We verwijzen onder andere naar Alphonse Baut, Octave de Blondel. Burgemeesters die de letter van de wet willen toepassen, krijgen meer dan eens hevige kritiek te verduren. François Van Doorslaer, burgemeester van Aalter (1805-1815) en Knesselare (1806-1815), treedt ongemeen streng op tegen dienstweigeraars en deserteurs. Deze houding wordt hem door de ingezetenen niet in dank afgenomen : zijn huis wordt tot tweemaal toe geplunderd, hijzelf moet de biezen pakken naar Gent (februari 1814). Charles Bogaert, burgemeester van Geraardsbergen (1808-1830) laat de wetten inzake de conscriptie uitvoeren en treedt hard op tegen de Stevenisten. Een anonieme tijdgenoot beschuldigt deze 'wraakzuchtige, door het publiek gehate persoon' van fraude, politiek gekonkel, noem maar op. De prefect stelt geen vervolging in; het komt zijns inziens wel meer voor dat de meest toegewijden worden aangeklaagd.

De mandatenhonger van de notabelen beperkt zich niet tot het louter politieke terrein. Ook in semi- of niet-politieke organismen nemen ze het heft in handen. Hierbij denken we vooral aan culturele en caritatieve organismen : academies van teken-, schilder-, beeldhouw- en bouwkunde, sociëteiten van schone kunsten, burgerlijke godshuizen, bureaus van weldadigheid, etc. Botanische-, onderwijs- kundige-, economische- en 


\section{CONNY DEVOLDER}

geneeskundige organismen kunnen zich eveneens verheugen in een levendige belangstelling. Aldus manifesteren Jean-Baptiste d'Hane, Jean Vanderhaeghen, Charles Van Hulthem en Ignace Van Toers,... zich in alle geledingen van het openbaar leven. Tot slot vermelden we dat 14 notabelen thuis zijn in het maçonnieke milieu. Als voorbeeld halen we Pierre Gervaise, een prominent vrijmetselaar, aan.

\section{Algemeen besluit.}

Fortuin, macht en aanzien zijn geconcentreerd in handen van deze kleine, door verwantschaps- en vriendschapsbanden verbonden groep, waarvan een grote meerderheid gedomicilieerd is in Gent, hoofdstad van het departement, geboortestad van zeker de helft van de 105 notabelen. Acht notabelen zijn van Franse herkomst. Anno 1800 zijn onze studie-objecten gemiddeld 42 jaar oud. Uit het onderzoek komt Napoleons streven om de grote eigenaars, negocianten en industriëlen, evenals de gefortuneerde en geachte personaliteiten aan het regime te hechten, duidelijk naar voor. Het is opvallend dat een tijd, die op institutioneel en economisch gebied zo vernieuwend is, in een niet onbelangrijke mate aanleunt bij sociale middens die reeds voor de Brabantse Omwenteling een vooraanstaande plaats bekleedden.

Bijlage : Naamlijst van de notabelen.

\section{BAUT Alphonse}

BAUWENS Liévin

BAZENERYE Andre

BEYENS Albert

BEYENS Constantin

BEYTS Pierre

BLEMONT

BLONDEL Emmanuel

BOGAERT Charles

BRUSSELMAN Jean

CHATILLON Romain

CLAVAREAU Auguste

CLEMMEN François

CLEMMEN Jean

DANNEELS Thomas

DE BAIILET Alexandre

DE BLONDEL Octave

DE BLONDEL Pierre 


\section{DE NOTABELEN VAN HET SCHELDEDEPARTEMENT}

DE CLERCQ Guillaume

DE DRAECK Gaspard

DE DRAECK Louis

DE GAGE Emmanuel

DE GHELLINCK Jean-Baptiste-Joseph

DE GHELLINCK Jean-Baptiste-Pierre

DE JONGHE Théodore

DE KERCHOVE Jean

DE LICHTERVELDE François

DELLA FAILLE Emmanuel

DELLA FAILLE Joseph

DE LOOSE Jean

DE LOOSE Pierre

DE MEULENAERE Pierre

DE NAEYER Francçois

DE NAEYER Jacques

DE POTTER Edouard

DE POTTER Louis

DE SMET Hubert

DE THIENNES François

DE VAERNEWYCK Charles

DE VOS Alexandre

DHAENE

D'HANE Jean-Baptiste

DONS Jean

DU VASIER

EEMAN Ferdinand

ESMANGART Claude

EVERAERT Jean-Baptiste

FONSON Albert

FOSTIER Jean

GERVAISE Pierre

HOELANDS Jean

HOPSOMERE Constant

KERVYN Charles

KETELE Mathieu

LIMNANDER Jacques

LIPPENS Philippe

MAELCAMP Charles

MAES Pierre/Judocus

MEAULLE Jean

MESDACH Guillaume 
MOREL Alphonse

MUGUET PierTe

OTTEVAERE François

OUDAERT Charles

PAPELEU Denis

PIERS Augustin

PIERS Emmanuel

POELMAN Guillaume

RISSEEUW Jacques

RODRIGUEZ Charles

RODRIGUEZ Emmanuel

SCHAMP Jean-Baptiste

SCHAMP Jean-Gilles

SOENENS Jean-Baptiste

STALINS Charles

TEGEL_BERG Isaac

TINEL Pierre

VAN AKEN Norbert

VAN ALSTEIN Edouard

VAN ALSTEIN Joseph

VAN CANEGHEM Jacques

VAN CAZELE Ghisbert

VAN DEN HECKE Louis

VAN DEN HECKE Philippe

VANDERBEKEN Jean

VANDERHAEGHEN Armand

VANDERHAEGHEN Jean

VANDERHAEGHEN Philibert

VAN DER MEERE Charles

VAN DOORSLAER François

VAN ERTBORN Joseph

VAN GOBBELSCHROY PierTe

VAN HOOBROUCK Eugène

VAN HULTHEM Charles

VAN OVERLOOP Philippe

VAN RAEDEN Henri

VAN ROCKOLFING Louis

VAN SACEGHEM Thadé

VAN TOERS Ignace

VAN WAMBEKE Bemard

VERBERCKMOES Pierre

VERSMESSEN Antoine 
DE NOTABELEN VAN HET SCHELDEDEPARTEMENT

VERSMESSEN Jean-Baptiste

VILAIN XIIII Charles

VILAIN XIIII Philippe 